\title{
Perilaku Menyusui pada Ibu dengan HIV-AIDS di Kota Yogyakarta
}

\author{
Breastfeeding Behavior in Mothers with HIV-AIDS in Yogyakarta
}

\author{
Faizia Maulida, Pariawan Lutfi Ghazali* \\ Fakultas Kedokteran Universitas Islam Indonesia Yogyakarta \\ ('elghazali@uii.ac.id)
}

\begin{abstract}
ABSTRAK
World Health Organization (WHO) merekomendasikan pemberian ASI eksklusif selama 6 bulan untuk anak yang lahir dari ibu terinfeksi HIV yang telah mendapatkan terapi ARV. Penelitian ini bertujuan mengetahui persepsi, perilaku, dan faktor yang mempengaruhi perilaku menyusui pada ibu dengan HIV-AIDS di Yogyakarta. Penelitian ini menggunakan metode kualitatif dengan wawancara mendalam dan observasi sebagai metode pengambilan data. Subjek penelitian adalah ibu menyusui dengan HIV-AIDS, keluarga, dan pendamping. Validitas data diuji dengan metode triangulasi sumber. Data penelitian diolah dengan metode perbandingan tetap. Penelitian ini menunjukkan bahwa ibu menyusui dengan HIV-AIDS di Yogyakarta berpendapat proses memberikan asupan gizi kepada bayi merupakan kodrat seorang perempuan yang tidak dapat digantikan oleh siapapun. Perilaku menyusui ibu dengan HIV-AIDS di Yogyakarta terbagi menjadi ibu yang memberikan susu formula, ASI, dan donor ASI. Faktor yang memengaruhi perilaku menyusui ibu dengan HIV-AIDS di Yogyakarta, yaitu faktor internal dan dukungan dari keluarga, pendamping, tenaga kesehatan, serta teman sebaya. Penelitian ini menyimpulkan bahwa ibu menyusui dengan HIV-AIDS memiliki alasan terkait risiko penularan HIV dalam memutuskan perilaku menyusui. Kata kunci: Perilaku, menyusui, HIV-AIDS
\end{abstract}

\begin{abstract}
The World Health Organization (WHO) recommends exclusive breastfeeding for 6 months for children born to HIV infected mothers who have received ARV therapy. This study aims to determine perceptions, behaviors, and factors that influence breastfeeding behavior in mothers with HIV-AIDS in Yogyakarta. This study use qualitative research method, with in-depth interviews and observation as data collection methods. Research subjects were breastfeeding mothers with HIV-AIDS, family, and chaperones. Data validity was tested by source triangulation method. Research data were processed using the fixed comparison method. This research shows that breastfeeding mothers with HIV-AIDS in Yogyakarta believes that the process of providing nutrition to infants is the nature of a woman that can not be replaced by anyone. The behavior of breastfeeding mothers with HIV-AIDS in Yogyakarta is divided into mothers who provide formula milk, breast milk, and donor breast milk. Factors that influence breastfeeding behavior of mothers with HIV-AIDS in Yogyakarta, namely internal factors and support from family, chaperones., health workers, and peers. This research concludes that breastfeeding mothers with HIV-AIDS have reasons related to the risk of HIV transmission in deciding breastfeeding behavior.
\end{abstract}

Keywords: Behavior, breastfeeding, HIV-AIDS

Copyright (C) 2019 by author. This is an open access article under the CC BY-NC-SA license

(https://creativecommons.org/licenses/by-nc-sa/4.0/).

DOI : http://dx.doi.org/10.30597/mkmi.v15i4.7931 


\section{PENDAHULUAN}

Human Immunodeficiency Virus (HIV) Acquired Immuno-Deficiency Sindrome (AIDS) merupakan salah satu masalah besar yang dihadapi oleh dunia hingga saat ini. Jumlah penderita HIV di seluruh dunia pada tahun 2016 adalah 36,7 juta orang dan jumlah kematian akibat AIDS sebanyak 1,5 juta jiwa. ${ }^{1}$ Jumlah penderita HIV-AIDS di Asia Selatan dan Tenggara sekitar 4 juta orang dengan 1,3 juta $(37 \%)$ di antaranya adalah perempuan. ${ }^{1}$ Data statistik menunjukkan, jumlah penderita HIV di Indonesia sebanyak 150.296 orang dan AIDS sebanyak 55.799 orang, dengan angka kematian sebesar 9.796. ${ }^{2}$ Jumlah kumulatif infeksi HIV di DIY pada tahun 2015 sebanyak 1875 dan AIDS sebanyak 1231, dengan kota Yogyakarta menempati urutan tertinggi di DIY sebanyak 580 HIV dan 251 AIDS. ${ }^{3}$

Transmisi terbanyak dalam HIV-AIDS adalah melalui hubungan seksual, sehinggga perempuan termasuk ibu rumah tangga semakin rentan mengalami penularan, seiring dengan meningkatnya jumlah laki-laki yang melakukan hubungan seksual tidak aman. ${ }^{4}$ Hal ini sangat berbahaya karena perempuan mempunyai risiko tinggi (20$50 \%$ ) menularkan HIV ke anaknya dalam masa kehamilan (5-10\%), persalinan (10-20\%), maupun menyusui $(5-20 \%))^{1,5}$ Penularan HIV-AIDS dari ibu ke anak untuk wilayah Yogyakarta hingga triwulan 1 tahun 2015 sebanyak 70 orang. ${ }^{3}$

Program Pencegahan Penularan HIV dari Ibu ke Anak (PPIA) telah terbukti sebagai intervensi yang sangat efektif untuk mencegah penularan HIV dari ibu ke anak. ${ }^{5}$ Risiko anak tertular HIV dari ibu dapat ditekan hingga kurang dari $2 \%$ di negara maju, karena tersedianya intervensi PPIA dengan layanan optimal..$^{5}$ Namun, di negara miskin dengan minimnya akses intervensi maka risiko penularan masih tinggi (20-50\%). Program pencegahan penularan dari ibu ke anak terdiri dari 4 program yang merujuk pada rekomendasi WHO 2010, yaitu penawaran tes HIV pada semua ibu hamil, pemilihan kontrasepsi untuk ibu dengan HIV positif, pemilihan persalinan aman untuk ibu hamil yang HIV positif, dan pemberian makanan terbaik bagi bayi baru lahir dengan ibu HIV positif. $^{5}$

Makanan terbaik bagi bayi baru lahir adalah Air Susu Ibu (ASI), tetapi ASI juga salah satu jalan bagi penularan HIV dari ibu ke bayi. ${ }^{6,7}$ Maka bagi ibu dengan HIV, pemberian ASI harus didahului dengan konseling oleh petugas kesehatan dan konselor laktasi tentang risiko penularan HIV melalui ASI. ${ }^{5}$ Konseling diberikan sejak perawatan antenatal, dan ibu harus mendapatkan informasi secara lengkap tentang HIV-AIDS. WHO merekomendasikan pemberian ASI eksklusif selama 6 bulan untuk anak yang lahir dari ibu yang terinfeksi HIV dan telah mendapatkan terapi ARV. ${ }^{8}$ Hal ini bertujuan untuk kelangsungan hidup anak (HIV-free and child survival). ${ }^{9}$ WHO juga menganjurkan kepada ibu dengan HIV untuk tetap menyusui selama 12 bulan dan tetap dibarengi dengan terapi ARV yang adekuat. ${ }^{8}$ Penelitian ini bertujuan untuk mengetahui persepsi, perilaku, dan faktor yang mempengaruhi perilaku menyusui pada ibu dengan HIV-AIDS di Yogyakarta.

\section{BAHAN DAN METODE}

Penelitian ini menggunakan metode kualitatif. Data diambil dengan wawancara mendalam dan observasi. Penelitian ini dilakukan pada bulan April sampai dengan Desember 2016 di Kota Yogyakarta. Populasi dalam penelitian ini adalah seluruh ibu menyusui dengan HIV-AIDS di Kota Yogyakarta. Sampel penelitian (informan) dipilih secara purposive, sesuai kebutuhan penelitian, yaitu ibu menyusui dengan HIV-AIDS, pendamping dari ibu menyusui dengan HIV-AIDS, dan keluarga dari ibu menyusui dengan HIV-AIDS.

Validitas data diuji dengan metode triangulasi sumber. ${ }^{10}$ Data kemudian dianalisis dengan metode perbandingan tetap, yaitu reduksi data, koding, kategorisasi, labeling, sintesisasi dan hipotesis kerja. ${ }^{10}$ Izin etika penelitian dikeluarkan oleh Komite Etik Fakultas Kedokteran Universitas Islam Indonesia berdasarkan Surat Keterangan Lolos Kaji Etik Nomor 35/Ka.Kom.Et/70/ $\mathrm{KE} / \mathrm{V} / 2016$.

\section{HASIL}

Informan penelitian ini berjumlah 6 orang, terdiri dari 4 ibu menyusui dengan HIV-AIDS (kode: A1, A2, A3, A4), 1 keluarga dari ibu menyusui dengan HIV-AIDS (kode: B), dan 1 pendamping dari ibu menyusui dengan HIV-AIDS (kode: C). Informan yang memberikan ASI eksklusif sebanyak 1 orang (A3), sedangkan 3 orang lainnya 
memberikan susu formula.

Hasil wawancara mendalam dengan ibu menyusui dengan HIV-AIDS diperoleh informasi bahwa ibu menyusui dengan HIV-AIDS mempunyai persepsi yang positif mengenai perilaku ibu menyusui bayi. ASI merupakan asupan gizi terbaik untuk bayi, dengan menyusui dapat terjadi komunikasi antara ibu dan bayinya.

"Proses memberikan susu ke anak merupakan kodrat perempuan yang tidak dapat diwakilkan dan sebagai ikatan kasih sayang ibu ke anak. Menyusui tidak dapat digantikanolehsusu formula semahalapa-pun, karena ASI sudah terbukti makanan terbaik yang dibuat alami di tubuh" (Informan A3)

"Menyusui merupakan bentuk komunikasi antara ibu dan anak" (Informan A4)

"Menyusui memberikan gizi terbaik bagi anak" (Informan

Meskipun persepsi tentang menyusui positif, ibu menyusui dengan HIV-AIDS lebih banyak menggunakan susu formula, dan hanya ada beberapa yang memberikan ASI eksklusif kepada anaknya (B). Donor ASI kadang digunakan tetapi sering menemui kesulitan sehingga tidak berlanjut (B). Keputusan memberikan ASI eksklusif maupun susu formula dilakukan setelah mendapatkan pengarahan dan konsultasi dengan tenaga kesehatan dari puskesmas (A1, A2, A3). Tenaga kesehatan dari puskesmas memberikan pengetahuan dan keterampilan tentang cara menyusui yang benar, sehingga ibu menyusui dengan HIV-AIDS dapat menerapkannya dalam rutinitas menyusui. Ibu menyusui dengan HIV-AIDS yang tidak memberikan ASI eksklusif merasa khawatir dengan pertanyaan lingkungan sekitar mengenai alasan tidak memberikan ASI (A1). Hal tersebut disebabkan oleh norma masyarakat yang mengharuskan ibu untuk menyusui bayinya, meskipun masyarakat sendiri tidak terlalu memahami makna ASI eksklusif, bagi mereka yang penting ibu menyusui (B).

Bayi yang diberikan susu formula pada 6 bulan pertama hanya diberikan susu formula saja. Selanjutnya setelah berusia 6 bulan diberikan makanan pendamping berupa vitamin $\mathrm{C}$ dan buah pisang (A1, A2, A4). Ibu menyusui dengan HIVAIDS juga mengaku terkadang air putih diberikan 1-2 tetes saat bayi sudah lapar, tetapi belum saatnya pemberian susu (A2). Pemberian susu formula ada yang menggunakan botol dot (A1), meskipun tenaga kesehatan mengajarkan bahwa cara pemberian susu formula yang baik adalah dengan menggunakan sendok dan gelas, dengan disendokkan perlahan-lahan (B, C). Penggunaan botol dot dilakukan karena berpendapat cara pemberian menggunakan sendok terlalu lama dan anak sering rewel (A1). Ibu sebenarnya menyadari bahwa botol dot berisiko, seperti gangguan pertumbuhan gigi dan infeksi, tetapi telah dikonsultasikan ke dokter anak, dan diperbolehkan dengan ketentuan dijaga kebersihannya (A1). Ibu yang lain meminumkan susu formula langsung dari gelas (A4, C) dan menggunakan sendok alumunium dan gelas kaca untuk memberikan susu formula pada bayinya (A2). Semua narasumber ibu-ibu menyusui dengan HIV-AIDS mengetahui bahwa penggunaan sendok dapat mengurangi risiko kuman, mudah mencucinya dan agar tidak tersedak.

Proses pembersihan dan sterilisasi alat-alat yang digunakan untuk memberikan susu formula dilakukan dengan air panas, sabun dan lap kering. Kebiasaan cuci tangan dengan sabun juga dilakukan sebelum memegang atau memberi susu bayi. Hal itu sesuai dengan yang diajarkan oleh tenaga kesehatan dari puskesmas.

Pemilihan susu formula disesuaikan dengan kondisi anak (A1, A2, A4). Jenis atau merek susu diganti ketika anak tidak cocok yang ditandai misalnya bayi mengalami muntah, badan kurus, merasa bosan, dan alergi (A1, A2, A4). Penambahan takaran air dilakukan oleh ibu di susu formula agar lebih encer, sehingga tinja anak tidak keras (A2, A4).

Ibu menyusui dengan HIV-AIDS harus disiplin dalam konsumsi obat Anti Retroviral (ARV) untuk dirinya dan untuk anaknya sebagai profilaksis. Berdoa kepada Tuhan juga merupakan hal penting, karena rasa khawatir dan stres yang dihadapi sangat besar (A3). Namun, ada ibu menyusui dengan HIV-AIDS yang tidak memberikan profilaksis kepada anaknya, karena merasa tidak perlu dan merasa berat bila harus memberikan obat setiap hari kepada anak (A4).

Ibu yang memberikan susu formula cende- 
rung merasakan sedih, karena tidak dapat memberikan yang terbaik bagi anaknya, yaitu ASI (A1). Mereka juga merasa khawatir kondisi kesehatan anaknya, akan tertular dan bernasib sama seperti ibunya (A2). Terdapat juga perasaan kecewa karena tidak dapat memberikan yang terbaik bagi anak dan keluarga dan merasa kurang sempurna (A2). Sisi lain mereka juga merasa bahagia ketika melihat perkembangan anaknya yang bagus dan badannya sehat (A1). Ibu yang memberikan ASI eksklusif selama menyusui merasa sangat tertekan sehingga membutuhkan seseorang yang mampu memberikan informasi yang tepat dan menenangkan dan juga merasa bersalah ketika asupan anaknya kurang (A3).

Faktor-faktor yang mempengaruhi perilaku menyusui ibu dengan HIV-AIDS dapat disimpulkan adalah (1) Keyakinan akan keputusan yang diambil, menggunakan ASI eksklusif atau susu formula; (2) Keberanian mengambil risiko dan manajemen stres; (3) Keyakinan dan kepercayaan akan kehendak Tuhan bahwa anak adalah amanah dan anugerah; (4) Dukungan dan perhatian dari keluarga, terutama suami, termasuk bantuan teknis pemberian ASI atau susu formula dan tugas lain; (5) Bantuan finansial dari keluarga atau pihak lain; (6) Dukungan tenaga kesehatan, khususnya yang terkait edukasi, terutama saat terjadi masalah saat pemberian ASI dan susu formula, (7) Dukungan dari kelompok pendamping, berupa edukasi, pengarahan, akses kesehatan dan finansial.

Teman sebaya (ibu menyusui dengan HIVAIDS) cenderung tertutup (B1), sehingga sangat sulit mendapatkan dukungan dari orang yang bernasib sama (A1, B). Masyarakat di lingkungan tempat tinggal juga cenderung untuk memberikan tekanan psikologis kepada ibu menyusui dengan HIV-AIDS. Misalnya, sering menanyakan mengapa tidak diberi ASI (A1), dan pertanyaan itu membuat ibu menyusui dengan HIV-AIDS menjadi tertekan dan khawatir jika penyakitnya diketahui atau dicurigai oleh lingkungan sekitar (B).

Selain pemberian ASI eksklusif dan susu formula, terdapat juga pilihan lain yaitu donor ASI. Donor ASI belum terlalu dikenal di masyarakat. Informan mengaku bahwa belum pernah mendapat edukasi mengenai donor ASI, hanya sebatas mendengar (A1, A2), dan menemui kesulitan ketika harus menghubungi pihak donor (A4, B).
Ibu menyusui dengan HIV-AIDS lebih memilih susu formula dibandingkan donor ASI (A1, A4). Pertimbangan lain untuk tidak donor ASI adalah secara hukum agama akan memunculkan saudara sepersusuan (A3).

Hambatan dalam pengambilan keputusan untuk menyusui atau tidak adalah edukasi kurang adekuat, sehingga para ibu dengan HIV-AIDS merasa khawatir dan takut dapat menularkan virus ke bayinya (A3, B) dan juga kurangnya edukasi mengenai ASI eksklusif, terutama edukasi dari tenaga medis (B). Edukasi belum menyeluruh dan kurang memfasilitasi keinginan dari ibu dengan HIV-AIDS (A4).

Hambatan dalam pelaksanaan yang paling sering muncul dalam memberikan susu formula adalah masalah biaya. Penggunaan susu formula membuat pengeluaran sehari-hari bertambah (A1, A2, A4). Hambatan lain adalah persiapan maupun proses pemberian susu formula dirasakan rumit, memerlukan waktu dan membutuhkan tenaga, misalnya menyiapkan air panas saat berpergian (A1, A3).

Tenaga kesehatan dan pemerintah diharapkan dapat memberikan edukasi yang membuat ibu dengan HIV-AIDS merasa aman dan nyaman dan juga kampanye bahwa ibu dengan HIV-AIDS bisa menyusui (A4, B), sebaiknya terdapat standar yang benar, jelas, dan dapat dipertanggung jawabkan, sehingga informasi yang diterima oleh ibu dengan HIV-AIDS di manapun sama (B).

\section{PEMBAHASAN}

Ibu dengan HIV-AIDS mempunyai persepsi positif tentang menyusui. Persepsi tersebut merupakan tanggapan atau penerimaan langsung dari suatu hal, dan terdapat beberapa faktor yang mempengaruhinya, antara lain pengalaman di masa lalu, orang di sekitarnya, situasi, motivasi dan kepribadian. ${ }^{11}$ Penelitian lain juga menyatakan perempuan dengan HIV-AIDS mempunyai persepsi positif tentang menyusui. ${ }^{12,13}$ Penerimaan informasi dari petugas kesehatan juga menjadi hal yang mempengaruhi persepsi dan perilaku menyusui. ${ }^{14}$ Dukungan dari dari kelompok sebaya sangat penting bagi orang dengan HIV-AIDS, yang cenderung tertutup secara sosial. Dukungan ini akan mempermudah penyampaian informasi dengan asumsi bahwa seseorang akan lebih berse- 
dia mendengarkan jika pesan-pesan disampaikan oleh orang yang berasal dari lingkungan mereka sendiri, atau memiliki latar belakang sosial yang lebih kurang sama. ${ }^{15}$

Penelitian ini menunjukkan bahwa ada keinginan yang kuat dari ibu dengan HIV-AIDS untuk menyusui anaknya karena ikatan kasih sayang yang kuat. ${ }^{16}$ Secara fisiologis, setelah melahirkan hormon oksitosin pada perempuan akan meningkat dan memicu timbulnya perasaan sayang kepada bayinya, dan terbentuknya bonding. Bonding yang terbentuk membuat ibu menjadi lebih sensitif dan responsif terhadap kebutuhan bayinya. ${ }^{17}$ Bonding juga berhubungan dengan kontak kulit atau skin-to-skin contact, yang membantu bayi menjadi mudah ditenangkan bila menangis, mempercepat perkembangan lingual, sosial, motorik kasar, motorik halus pada usia 1 tahun, dan memiliki kontrol emosial yang lebih baik. ${ }^{18}$ Kondisi inilah yang harus terjadi, meskipun ibu menderita HIV-AIDS, anak tetap berhak mendapatkan bonding dengan ibunya, selain karena ASI mengandung gizi yang diperlukan oleh bayi dan sesuai dengan saluran percernaan bayi kekentalannya. ${ }^{19}$ Hal ini sesuai dengan beberapa penelitian yang menyatakan bahwa perempuan dengan HIVAIDS mempunyai kecenderungan untuk tetap menyusui anak yang dilahirkannya. ${ }^{12,20}$

Ibu menyusui dengan HIV-AIDS dalam penelitian ini menyadari bahwa ASI merupakan nutrisi terbaik bagi bayinya. Mereka merasa sedih dan kecewa terhadap dirinya ketika tidak memberikan ASI kepada bayinya. Sisi lain, kekhawatiran yang dirasakan ibu terkait menularkan penyakitnya pada bayinya menyebabkan ibu menyusui dengan HIV-AIDS berada dalam kebimbangan untuk memberikan ASI kepada bayinya. ${ }^{21}$ Kekhawatiran penyakit ibu menular kepada bayinya tersebut terjadi sejak ibu dengan HIV-AIDS hamil dan terus berlanjut hingga ibu menyusui. ${ }^{22}$ Ibu dengan HIV positif dihadapkan pada berbagai tantangan saat mereka berusaha untuk praktik pemberian ASI eksklusif. ${ }^{21}$ Oleh karenanya, konseling diberikan sejak perawatan antenatal, dan ibu harus mendapatkan informasi secara lengkap tentang HIV-AIDS. ${ }^{5}$

Ibu menyusui dengan HIV-AIDS memilih tidak memberikan ASI kepada bayinya karena pemberian ASI kepada bayinya dianggap berisiko tinggi menularkan penyakitnya kepada bayinya. ${ }^{23}$
World Health Organization (WHO) menganjurkan kepada ibu dengan HIV untuk tetap menyusui selama 12 bulan, namun tetap harus dibarengi dengan terapi ARV yang adekuat. ${ }^{8}$ Terapi ARV tersebut harus diberikan setiap hari baik untuk ibu maupun bayinya. Minum ARV dan memberikan ARV kepada bayi justru menjadi beban berat bagi ibu menyusui dengan HIV-AIDS. Hal tersebut merupakan faktor lain yang menyebabkan ibu menyusui dengan HIV-AIDS lebih memilih susu formula sebagai pengganti ASI. ${ }^{21}$

Pemberian susu formula kepada bayi baru lahir berisiko terjangkit diare. Risiko diare pada bayi baru lahir yang mengonsumsi susu formula sangat mungkin terjadi pada bayi dari ibu dengan HIV-AIDS. Pemahaman risiko pemberian susu formula perlu disampaikan kepada ibu menyusui dengan HIV-AIDS agar mereka memahami bahwa setiap pilihan yang dipilih mempunyai risiko yang harus ditanggung. Konsekuensi lain dari pemberian susu formula adalah biaya yang lebih mahal pemberian susu formula dibandingkan ASI. ${ }^{7}$ Pemberian ASI maupun susu formula pada bayi dari ibu dengan HIV-AIDS dibenarkan, selama memenuhi syarat yang telah ditentukan dan bersedia menerima konsekuensinya. ${ }^{5}$ Penelitian lain menunjukkan hasil yang sama dengan penelitian ini, yaitu adanya variasi pemberian makanan pada bayi dari ibu dengan HIV-AIDS. 12,13,20

Penggunaan botol dot untuk memberikan ASI dan susu formula masih dilakukan, meskipun ibu mengetahui risiko bagi kesehatan bayinya. Penggunaan botol dot dapat menimbulkan infeksi, seperti otitis media akut. ${ }^{24} \mathrm{Hal}$ tersebut dapat terjadi karena tekanan rongga telinga tengah dan nasofaring tidak seimbang, sehingga dapat merusak fungsi tuba eustachius, ketika bayi menyedot melalui dot dapat menarik cairan dari kerongkongan ke saluran telinga tengah. ${ }^{24}$ Penggunaan botol dot plastik pada temperatur tinggi akan menyebabkan terjadinya migrasi monomer-monomer bahan dasar plastik yang dapat bercampur dengan makanan..$^{25}$ Hygiene dan sanitasi dalam pemberian susu formula diatur dalam Permenkes Nomor 39 tahun 2013, yaitu (1) Mencuci tangan dengan sabun dan dibilas pada air mengalir sebelum menyajikan susu formula bayi; (2) Mencairkan susu dengan air mendidih kemudian ditunggu 10 menit, melihat petunjuk takaran pada kemasan 
atau mengikuti saran dokter; (3) Jika dalam 2 jam susu tidak habis maka harus dibuang; (4) Memperhatikan tanggal kadaluarsa dan keutuhan kemasan,(5) Mencuci setiap bagian alat dan rebus alat dengan air mendidih. ${ }^{26}$

Alternatif aman untuk memberikan ASI kepada bayi dari ibu dengan HIV-AIDS adalah ASI donor, tetapi ASI donor belum populer. ASI donor belum menjadi pilihan utama bagi ibu menyusui dengan HIV-AIDS berkaitan dengan agama yang dianut. ASI donor dianggap akan menyebabkan saudara sepersusuan. ${ }^{27}$ Ajaran dalam Agama Islam saudara persusuan tidak boleh (haram) menikah. Masalah ini bisa diatasi dengan perbaikan manajemen pemberian ASI donor. Ibu dengan HIV-AIDS atau keluarganya dapat menjelaskan kepada anaknya mengenai siapa saudara persusuannya. Fatwa Majelis Ulama Indonesia Nomor 28 Tahun 2013 telah mengatur masalah donor ASI yang secara garis besar menyatakan bahwa seorang ibu boleh memberikan ASI kepada anak yang bukan anak kandungnya, demikian juga sebaliknya sepanjang memenuhi ketentuan syar'i, yaitu ibu harus sehat, baik fisik dan mental, dan tidak sedang hamil. ${ }^{27}$

Rekomendasi WHO untuk ibu menyusui dengan HIV positif adalah (1) Tidak menyusui sama sekali, bila pengadaan susu formula dapat diterima, mungkin dilaksanakan, terbeli, berkesinambungan dan aman (Acceptable, Feasible, Affordable, Sustainable, Safe/AFASS); (2) Bila ibu dan bayi dapat diberikan obat-obat ARV (Anti Retroviral) dianjurkan menyusui eksklusif sampai bayi berumur 6 bulan dan dilanjutkan menyusui sampai umur bayi 1 tahun bersama dengan tambahan makanan pendamping ASI yang aman, (3) Bila ibu dan bayi tidak mendapat ARV, maka ASI eksklusif yang harus diperah dan dihangatkan sampai usia bayi 6 bulan dilanjutkan dengan susu formula dan makanan pendamping ASI yang aman. ${ }^{5}$ Hal tersebut juga dikuatkan oleh rekomendasi dari WHO, dalam pedoman $H I V$ and Infant Feeding, bahwa ibu yang telah mendapat terapi ARV selama 6 bulan dapat memberikan ASI kepada bayi, setelah pemberian 6 bulan dapat dilanjutkan hingga 12 bulan beserta makanan pendamping. ${ }^{28}$ Adanya panduan dari WHO, pihak-pihak yang terkait, khususnya perempuan dengan HIV-AIDS dapat lebih mudah memutuskan untuk memberikan ASI atau tidak pada anaknya.
Ibu seharusnya tidak mempunyai hambatan sosial budaya untuk memilih makanan alternatif atau tidak ada rasa takut akan stigma dan diskriminasi. ${ }^{29}$ Namun, stigma dan diskriminasi masih dirasakan oleh ibu dengan HIV-AIDS, terutama bagi yang memutuskan memberikan susu formula pada bayinya. ${ }^{7}$ Salah satu faktor yang mempengaruhi perilaku menyusui ibu dengan HIV-AIDS di Kota Yogyakarta adalah faktor psikis, termasuk di dalamnya meliputi kepercayaan diri dan komitmen untuk menyusui. ${ }^{30}$ Keinginan dari dalam diri merupakan hal yang penting. Kepribadian juga mempengaruhi dalam pengambilan risiko, ada yang cenderung menghindar, ada juga merasa sangat yakin sanggup untuk menghadapi. ${ }^{31}$ Ibu menyusui dengan HIV-AIDS merasa takut terhadap risiko yang akan didapatkan. Ketakutan dapat berupa ketidakpastian masa depan, anak tertular, dan stigma negatif masyarakat mengenai HIVAIDS. ${ }^{32}$ Pemikiran dan perasaan (thought and feelings) ataupun pertimbangan pribadi seseorang mengenai sesuatu hal adalah modal awal dalam bertindak atau berperilaku. ${ }^{31}$ Dukungan keluarga sebagai faktor dominan bagi ibu menyusui, sangat diperlukan terutama dalam kondisi psikis tertekan. ${ }^{33}$

Berdasarkan teori Green, faktor penguat (reinforcing factors) berperan dalam pembentukan perilaku, misalnya upaya petugas kesehatan, tokoh masyarakat, atau tokoh agama, dan yang paling penting dukungan keluarga, dapat berupa finansial atau tenaga. ${ }^{31}$ Ibu menyusui dengan HIV-AIDS juga akan berusaha untuk mendapatkan kenyamanan dan bantuan informasi dari orang lain untuk menyelesaikan masalahnya, terutama dari petugas pelayanan HIV-AIDS yang handal. ${ }^{34,35}$ Namun, dalam kondisi sulit ibu menyusui dengan HIV-AIDS akan cenderung menggunakan strategi emotional focused coping, yang cenderung tertutup dan tidak mau berbagi cerita dengan orang lain. ${ }^{34}$

\section{KESIMPULAN DAN SARAN}

Persepsi menyusui menurut ibu dengan HIV-AIDS di kota Yogyakarta adalah positif. Pemilihan memberikan ASI eksklusif atau susu formula pada bayinya, berdasarkan pertimbangan dan saran petugas kesehatan. Perilaku tersebut dipengaruhi oleh dukungan dari keluarga, edukasi 
dan dukungan dari tenaga kesehatan, serta dukungan kelompok pendamping. Penelitian terkait faktor yang mempengaruhi perilaku menyusui pada ibu dengan HIV-AIDS masih perlu dilakukan penelitian dengan metode kuantitatif untuk mengukur parameter-parameter terkait ibu dengan HIV-AIDS. Kementerian kesehatan, melalui dinas kesehatan dan puskesmas sebaiknya membuat program pendampingan khusus bagi ibu dengan HIV-AIDS dalam proses kehamilan, persalinan, dan menyusui.

\section{DAFTAR PUSTAKA}

1. World Health Organization. HIV/AIDS: Data and statistics [Online Report]. 2015. Available at: https://www.who.int/hiv/data/en/

2. Kemenkes RI. Profil Kesehatan Indonesia Tahun 2013. Jakarta: Kementerian Kesehatan RI; 2014.

3. Komisi Penanggulangan AIDS DIY. Profil Data HIV/AIDS. Yogyakarta: Komisi Penanggulangan AIDS DIY; 2015.

4. World Health Organization. Indonesia HIV Country Profile: 2014 [Online Report]. 2015. Available at: http://cfs.hivci.org/country-factsheet.html

5. Kemenkes RI. Pedoman Manajemen Program Pencegahan Penularan HIV dan Sifilis dari Ibu ke Anak. Jakarta: Kementerian kesehatan RI; 2015. Available at: http://siha.depkes.go.id/portal/files_upload/Pedoman_Manajemen PPIApdf.pdf

6. IDAI. Indonesia Menyusui. [Edisi 1]. Jakarta: Ikatan Dokter Anak Indonesia; 2010.

7. Suradi R. Tata Laksana Bayi dari Ibu Pengidap HIV/AIDS. Sari Pediatri. 2003;4(4):180-185.

8. World Health Organization. Guideline on When to Start Antiretroviral Therapy and on Pre-Exposure Prophylaxis for HIV [Edisi 1]. World Health Organization; 2015.

9. World Health Organization. Mother-to-Child Transmission of HIV [Report Online]. 2015. Available at: https://www.who.int/hiv/topics/ $\mathrm{mtct} / \mathrm{en} /$

10. Moeloeng LJ. Metodologi Penelitian Kualitatif. Bandung: Remaja Rosdakarya; 2017.

11. Jalaludin Rakhmat. Psikologi Komunikasi. Bandung: Remaja Rosdakarya; 2017.

12. Umeobieri A, Mbachu C, Uzochukwu BSC,
Elias A, Omotowo B, Agunwa C, et al. Perception and Practice of Breastfeeding among HIV Positive Mothers Receiving Care for Prevention of Mother to Child Transmission in South-East, Nigeria. International Breastfeeding Journal. 2018;13(50):1-8.

13. Gejo NG, Gebrehiwot H, Weldearegay, Tesfay K, Ermias D, Mekango, et al. Exclusive Breastfeeding and Associated Factors among HIV Positive Mothers in Northern Ethiopia. PLoS One. 2019;14(1):1-10.

14. Thaha ILM, Razak R, Ansariadi. Determinants of Exclusive Breastfeeding among Muliparous in Jeneponto. Media Kesehatan Masyarakat Indonesia. 2015;11(4):247-252.

15. Haerana BT, Salfiantini, Ridwan M. Increased Comprehensive Knowledge of HIV and AIDS Through the Peer Group. Media Kesehatan Masyarakat Indonesia. 2015;11(2):132-138.

16. Cuinhane CE, Coene G, Roelens K, Vanroelen C. Exploring Perceptions and Practices of Biomedical Norms during Exclusive Breastfeeding among HIV-Positive Lactating Mothers in Mozambique. Journal of AIDS \& Clinical Research. 2017;8(4):1-11.

17. Britton J, Britton H, Gronwaldt V. Breastfeeding, Sensitivity, and Attachment. Pediatrics. 2006;118(5):1436-1443.

18. ICEA. Skin-to-Skin Contact. [Position Paper]. Raleiigh, North Carolina, USA: International Childbirth Education Association; 2015. Available at: https://icea.org/wp-content/uploads/2016/01/Skin_to_Skin_Contact PP.pdf

19. Hendarto A, Pringgadini K. Nilai Nutrisi Air Susu Ibu. In: Hegar B, Suradi R, Hendarto A, Partiwi IG. Bedah ASI. [Edisi 1]. Jakarta: Ikatan Dokter Anak Indonesia; 2008. pp 45-97.

20. Hazemba AN, Ncama BP, Sithole SL. Promotion of Exclusive Breastfeeding among HIV-Positive Mothers : an Exploratory Qualitative Study. International Breastfeeding Journal. 2016;11(9):1-10.

21. Aishat U, David D, Olufunmilayo F. Exclusive Breastfeeding and HIV/AIDS: a Cross Sectional Survey of Mothers Attending Prevention of Mother-to-Child Transmission of HIV Clinics in Southwestern Nigeria. The Pan 
African Medical Journal. 2015;21(309):1-6.

22. Elisa, Parwati DM, Iis Sriningsih. Pengalaman Ibu yang Terdeteksi HIV tentang Dukungan Keluarga Selama Persalinan. Jurnal Kesehatan Masyarakat. 2012;8(1):35-41.

23. Crawley S, Wall S, Serghides L, Dryer M. Feedback-Guided Development for Patient Education Animation : HIV Transmission via Breastfeeding. The Joyrnal of Biocommunication. 2018;42(2).

24. Ari Yunanto. Masalah Penggunaan Dot pada Bayi. [Article Online]. Jakarta: Ikatan Dokter Anak Indonesia; 2013. Available at: http://www.idai.or.id/artikel/klinik/asi/masalah-penggunaan-dot-pada-bayi

25. Sulchan M, Nur E. Keamanan Pangan Kemasan Plastik dan Styrofoam. Majalah Kedokteran Indonesia. 2007;57(2):54-59.

26. Permenkes Nomor 39 Tahun 2013. Tentang Susu Formula Bayi dan Produk Bayi Lainnya. Jakarta: Kementerian Kesehatan RI.

27. MUI. Seputar Masalah Donor Air Susu Ibu (Istirdla'). Jakarta: Majelis Ulama Indonesia; 2013.

28. World Health Organization. HIV and Infant Feeding. [Report Online]. 2015. Available at: https://www.who.int/maternal_child_adoles- cent/topics/child/nutrition/hivif/en/

29. Besar DS, Eveline P. Air Susu Ibu dan Hak Bayi. In: Hegar B, Suradi R, Hendarto A, Partiwi IG. Bedah ASI. [Edisi 1]. Jakarta: Ikatan Dokter Anak Indonesia; 2008. pp 1-15.

30. Arbon S, Byrne J. The Reliability of a Breastfeeding Questionnaire. Breastfeeding Review. 2001;9(2):23-32.

31. Notoatmodjo S. Ilmu Perilaku Kesehatan. Jakarta: Rineka Cipta; 2011.

32. Conroy DE, Kaye MP, Fifer A. Cognitive Links between Fear of Failure and Perfectionism. Jornal of Rational Emotive \& Cognitive Behaviour Therapy. 2007;25:237-253.

33. Ramadani M. Family's Support as the Dominant Factor of Exclusive Breastfeeding. Media Kesehatan Masyarakat Indonesia. 2017;13(1):34-41.

34. Nugroho P. Coping Stres pada Orang dengan HIV dan AIDS. [Tesis]. Malang: Universitas Muhammadiyah Malang; 2009.

35. Sutriani. The Relationship between HIV/ AIDS Care Service Quality and Patient Satisfaction in Labuang Baji Public Hospital, Makassar. Media Kesehatan Masyarakat Indonesia. 2013;9(4):212-220. 